\title{
FEES FOR ADVERTISEMENTS IN PUBLIC SPACE INCURRED BY A GIVEN BANK BRAND IN POLAND
}

\author{
Monika Płuciennik, M.Sc. \\ Department of Spatial Economy \\ Wroctaw University of Environmental and Life Sciences \\ e-mail:monika.pluciennik@up.wroc.pl \\ Maria Heldak, PhD \\ Department of Spatial Economy \\ Wrocław University of Environmental and Life Sciences \\ e-mail:maria.heldak@up.wroc.pl
}

\begin{abstract}
This article aims to present significant changes in the rates of fees for advertisements on selected bank buildings located in public space, resulting from the implementation of the so-called "Act on Landscape Protection" (Act on amending certain acts in connection with the strengthening of landscape protection tools from 24 April 2015 (2015 Journal Of Laws, item 774). The Act on landscape protection aims to minimize the amount of signboards in city centers. It introduces significant changes regarding (a) fees, (b) the expanded definition of advertisements, and (c) potential revisions and renewal of advertisements. The implementation of the Act causes significant inconveniences and challenges in the process advertising services. The objective of this research is to assess changes in the costs of advertising incurred by banks. More specifically, the research estimated (a) fees incurred by a selected bank brand for signboards placed on all bank branches within the entire country. An altered definition of an advertisement placed in the right-of-way and in public space will cause an increase in the surface of signboards, and, therefore, an increase in fees. In addition, a new type of fee (i.e., advertising fee) will increase the expenses incurred by the bank for the specified objects.
\end{abstract}

Key words: outdoor advertising, signboards, public space, right-of-way occupation, Act on landscape protection.

JEL Classification: C13, L85.

Citation: Płuciennik M., Hełdak M., 2017, Fees for Advertisements in Public Space Incurred by a Given Bank Brand in Poland, Real Estate Management and Valuation, vol. 25, no. 1, pp. 93-102.

DOI: 10.1515/remav-2017-0006

\section{Introduction}

Public space is a social space that is generally open and accessible to people. According to the definition in the Act on Spatial Planning and Development from March 27, 2003 (consolidated text, Journal Of Laws2015, Item 199 as amended), public space should be considered as an area of particular importance for meeting the needs of residents, improving their quality of life and enabling favorable social contacts, due to its location as well as functional and spatial characteristics. Additionally, such an area is specified in the study of conditions and directions of spatial development. Roads and streets, public squares and various permanently available buildings and constructions owned by the government, are some examples of public spaces.

In a public space we can find many signboards relaying product information. Outdoor advertising 
aims to show a service or a product to people who rarely acquire information through the media (BENEDIKT 2004). Outdoor advertising effectively affects the brand image, because "attention is attracted" and "may be received by even several senses" (KALINOWSKA 2007). This builds a relationship between the brand and client.

The term "Outdoor Advertising" corresponds to any advertisements located in open air, i.e. outdoor areas. An outdoor advertisement is the only advertising medium to which we are exposed involuntarily (GULMEZ, KARACA, KITAPCI 2010). Billboards are the most common and widely used forms among outdoor advertising media (e.g. BERKOVITZ, KERIN, HARTLEY 1994; TAYLOR, CHANG 1995; BHARGAVA, DONTHU, 1999; LichtenTHAL, YADAVA, DONTHUB 2006). When compared to other media tools, the share of outdoor advertisements as a proportion of total advertising expenditure is increasing, albeit slowly (GULMEZ, KARACA, KITAPCI 2010). As a result of enormous expenditures and the attention companies give to advertising their products and services effectively, consumers are exposed to more persuasive advertising pressure than ever before (NEUNER, RAAB, REISCH 2005; MikOŁAJCZAK-DEGRAUWE, BRENGMAN 2013).

Public space should be developed in a harmonious, structured manner, taking into account all functional, socio-economic, environmental, cultural and compositional-aesthetic conditions and requirements. Nowadays, the expansion of advertising, or what we may even refer to as the aggressiveness of advertising, is a very powerful phenomenon, which is associated with the development of technologies that offer virtually endless possibilities for creating advertisements (CZECH, KROPIWNICKA, OSTROWSKI 2014). Thus, the protection of landscapes from outdoor advertising is a very important problem that requires legal solutions.

The development of outdoor advertising under conditions of a free market economy is a difficultto-control process. However, as Lithuanian and foreign experience shows, the regulation of its placement and visual impact is essential if we are to preserve and enhance the visual quality and the individual identity of the landscape (KAMICAITYTE-VIRBASIENE, SAMUCHOVIENE 2013). Regulations regarding outdoor advertisement in Denmark are very strict. The country puts special emphasis on traffic safety and the landscape. FSBs (free-standing billboards) are prohibited everywhere except in urban areas, where permissions regarding their placement are issued by the municipalities (OUTDOOR ADVERTISING ... 2011).

In Poland, amendments of law, including the amendments to the Act on Spatial Planning and Development of March 27, 2003, gave the municipal council the power to determine the rules and conditions of locating street furniture, signboards and advertising devices as well as fences, and also their size, standards of quality and types of building materials which they can be made of. Furthermore, the Act on amending certain acts in connection with the strengthening of landscape protection tools from April 24, 2015, through the modification of the Act on Local Taxes and Fees of January 12, 1991, gave municipal councils the authority to establish advertising fees.

Amendments to the following laws were filed with the entry into force of the Act on amending certain acts in connection with the strengthening of landscape protection tools of April 24, 2015 (2015 Journal of Laws, Item 774):

1) Code of Petty Offences of May 20, 1971;

2) Act on Public Roads of March 21, 1985;

3) Act on Local Taxes and Fees of January 12, 1991;

4) Act on Construction Law of July 7, 1994;

5) Act on Spatial Planning and Development of March 27, 2003;

6) Act on the Preservation of Historic Monuments of July 23, 2003;

7) Act on Nature Conservation of April 16, 2004.

The series of amendments in the above Acts is to regulate the sustainable development of space. Nowadays, many municipalities are awaiting the implementation of "landscape protection rules", hence the topic of advertising is very important where bank finances are concerned, as well as in connection with the income of municipalities from advertising fees.

\section{Data and Methods}

The Act on amending certain acts in connection with the strengthening of landscape protection tools of April 24, 2015 (2015 Journal Of Laws, Item 774) became effective on September 11, 2015, thereby introducing significant changes in the functioning of many companies in Poland (including banks), which advertise their location among other commercial buildings. 
Before the Act on landscape protection, placing advertisements (signboards and banners) on selected bank buildings were fees collected for the occupation of the right-of-way. Such payments were regulated by the Act of 21 March 1985 on Public Roads (more: PŁUCIENNIK, HEŁDAK, WERNER 2015). The new regulations introduced new terms and definitions. They also established new types of fees, which augment the right-of-way occupation fee.

Due to the short duration of the Act on landscape protection, for as of the day of interpreting the data used in the present analysis, none of the researched municipalities have taken legal amendments in local law resulting from the Act. This paper presents an estimation of annual bank costs for locating signboards and banners in public space.

The study used source documents based on the authors' own direct observations. Information comprising source materials, which are the basis for the carried out studies, are not collected by government departments of public statistics or other units operating in the field of real estate.

The method of comparative analysis was used for the analysis of data. Payments for the availability of the right-of-way are compared in order to determine specific dependencies, such as identity, similarities or differences between features and facts.

This article aims to identify differences in fees and the methods of their calculation following by Act on landscape protection. The authors refer to research carried out before the law of landscape protection tools became effective (PŁUCIENNIK, HEŁDAK, WERNER 2015).

\section{Discussion}

\subsection{Modification of the definition of an advertisement}

The first and most important modification of the law made by the Act on landscape protection is the definition of an advertisement, which has been expanded to include new elements. Prior to the Act, an advertisement, pursuant to the Act on Public Roads, was termed as a carrier of visual information along with structural elements and fixings, placed in the road users' field of vision, which is not a sign in the understanding of regulations on signs and signals or information sign on public service buildings established by the municipality. The current definition refers to the Act on Spatial Planning and Development: an advertisement is to be understood as a billboard or advertising device, in the meaning of Art. 2, Points 16b and 16c of the Act of 27 March 2003 on Spatial Planning and Development (Journal of Laws of 2015. Pos. 199, 443 and 774), placed in the field of vision of road users, as well as any other carrier of visual information, along with its construction elements and fixings, which is not a traffic sign, defined in regulations issued pursuant to Art. 7 of the Law of 20 June 1997 - Road Traffic Law (Journal of Laws of 2012. Pos. 1137 as amended), an information sign placed by a municipality providing information on buildings located near the road - including public service buildings, an information sign on the form of monument conservation, or information board referring to the forms of environmental protection in accordance with Art. 115 of the Act of 16 April 2004 on Nature Conservation.

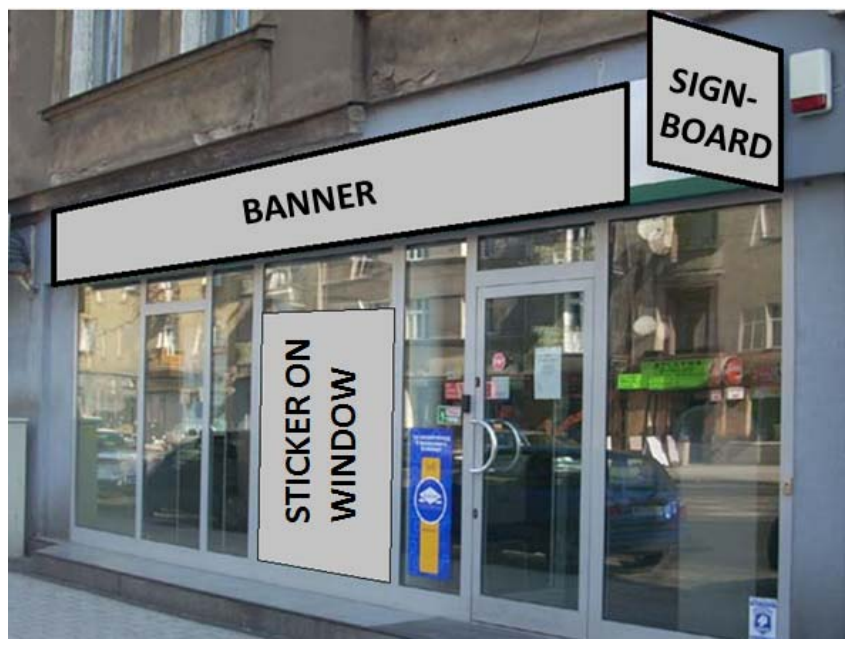

Fig.1. Banner, signboard, sticker on window. Source: own elaboration. 
Following the full wording of the definition of an advertisement, Art. 2 of the Act on Spatial Planning and Development describes a billboard as a flat object with structural elements and fixings, used for advertising exposure, in particular signboards and banners, advertisements attached to the windows of buildings, and advertisements placed on the scaffolding, fence or equipment of a construction site, with the exception of small, everyday items used for their intended purpose (Fig. 1). An advertising device is an object with structural elements and fixings, used for advertising exposure, other than a billboard, with the exception of small, everyday items used for their intended purpose.

Additionally, the Act on Spatial Planning and Development introduced a definition of signs; a sign is a billboard or advertising device, which informs one about the office or agency found inside the building.

The modification of the definition of an advertisement results in a change in objects treated as an advertisement in a road user's field of vision. Treated as an advertisement placed in the road users' field of vision. For the given bank brand, having 462 locations of bank outlets throughout Poland, the new characteristics, especially legally defining window stickers as advertisements, results in an increase in advertising surface by over $80 \%$ (Fig. 2).

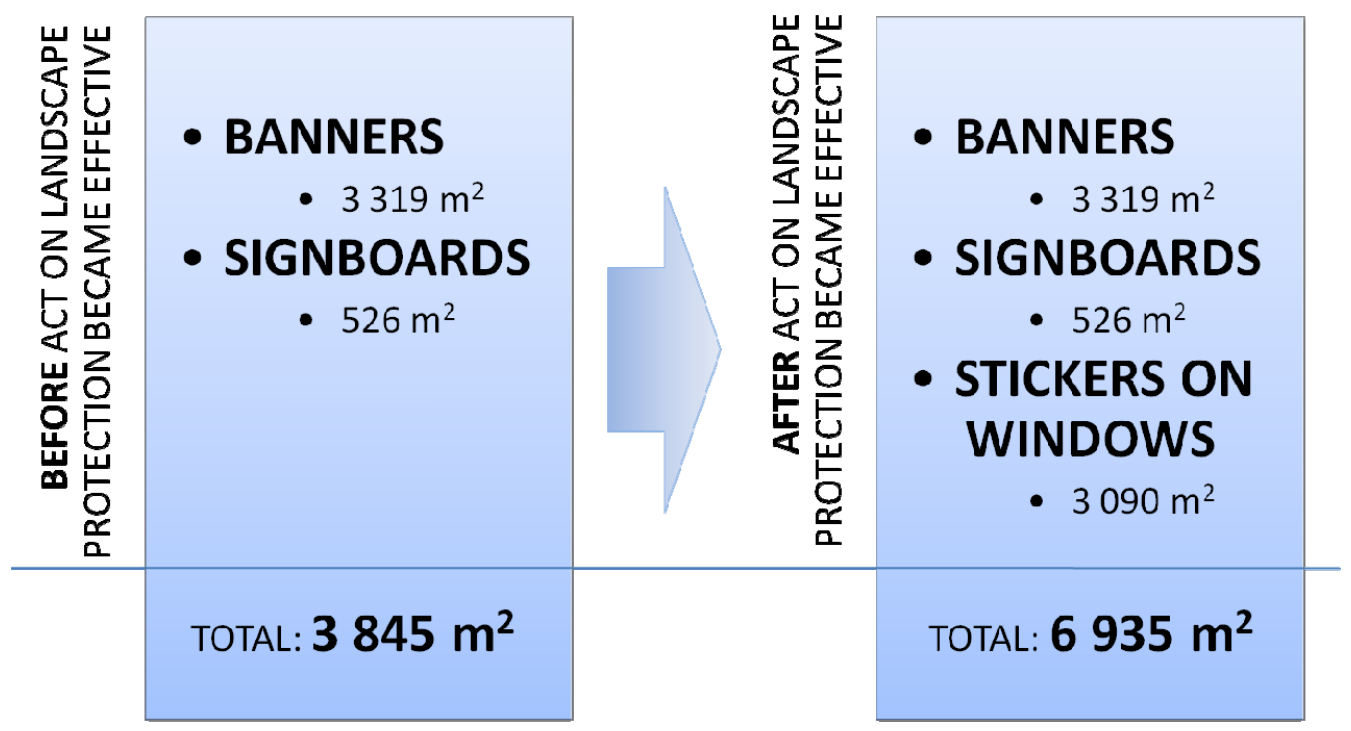

Fig.2. Total surface of outdoor advertising. Source: own study.

\subsection{Advertising Fee}

The Act on landscape protection introduced a new type of advertising fee. It is a source of additional expenses for bank brands. The introduction of an advertising fee provokes discussion and provides for various interpretations of the law.

An advertising fee is an extra payment in addition to the right-of-way occupation fee (Art. 40.6a, Act on Public Roads). Its explanation can be found in Art. 17a and Art.17b of the Act of 12 January 1991 on Local Taxes and Fees (Journal of Laws of $2014 \mathrm{r}$. Item 849 as amended).

An advertising fee can be established by the municipal council only for an area with binding rules and conditions of locating street furniture, signboards and advertising devices and fences. It should be paid whenever a hanging billboard or advertising device is placed on a building facade is, even if an advertisement does not appear on them.

An advertising fee is not always charged, especially when billboards and advertising devices:

1) are not visible from public space;

2) are a sign (compatibles with rules and conditions of locating objects of street furniture, signboards and advertising devices and fences);

3) are the implementation of an obligation imposed by the law;

4) are used exclusively to disseminate information:

a) permanently commemorating individuals, institutions or events;

b) of a religious nature, related to activities of churches and other religious organizations, if the billboard or advertising devices are within areas of worship and religious activities, or cemeteries. 
According to Art. $17 \mathrm{~b}$ of the Act on Local Taxes and Fees, an advertising fee $(A F)$ consists of a constant component $\left(A F_{C}\right)$ and a variable component $\left(A F_{V}\right)$. The constant section is a lump sum payment, regardless of the surface area of the billboard or advertising device. The variable part, in turn, depends on the surface area $(S)$.

$$
A F=\left(A F_{C}+A F_{V}^{*} S\right) * \text { time }
$$

The municipal council, in accordance with local law, determines the regulations regarding advertising fees (e.g. daily fees, payment dates). However, legislature imposes a maximum limit of the daily rate of the advertising fee:

- maximum rate of the constant part - 2.50 PLN per day;

- maximum rate of the variable component - 0.20 PLN per day for $1 \mathrm{~m}^{2}$ of the advertising surface. The Act on landscape protection has also introduced the possibility of differentiating the fee rates accounting for the location and size, or type of billboards and advertising devices.

One debatable clause in the Act on landscape protection is the clause regarding the constant component of the advertising fee, which covers a billboard or advertising device, regardless of its surface area. Thus, the following interpretations can be made:

1) the constant component of the fee is a single payment for one bank branch location;

2) the constant component of the fee is a payment for every kind of outdoor advertisement of a given bank branch location;

3) the constant component of the fee is a payment for every unit of outdoor advertising components of a given bank branch location, e.g. if the more than one of the windows are covered with stickers then each of the windows is counted separately for the payment.

A detailed comparison of each variant of interpretation has been presented in Table 1.

Calculating methods of the constant component of the advertising fee.

\begin{tabular}{|c|c|c|c|}
\hline & Variant 1 & Variant 2 & Variant 3 \\
\hline Determinant & $\begin{array}{c}\text { One bank branch } \\
\text { location }\end{array}$ & $\begin{array}{l}\text { kind of outdoor } \\
\text { advertising }\end{array}$ & $\begin{array}{l}\text { Individual unit } \\
\text { (component) of } \\
\text { advertisement }\end{array}$ \\
\hline $\begin{array}{l}\text { Number of charged } \\
\text { advertising objects }\end{array}$ & $\begin{array}{c}1 \text { object } \\
\text { (advertisement) }\end{array}$ & $\begin{array}{c}3 \text { objects (banner, } \\
\text { signboard, sticker on } \\
\text { windows ) }\end{array}$ & $\begin{array}{l}\text { depends on individual } \\
\text { components of an } \\
\text { advertisement for one } \\
\text { location }\end{array}$ \\
\hline $\begin{array}{l}\text { Maximum daily rates } \\
\text { of advertisement fee }\end{array}$ & 2.50 PLN/day & 7.50 PLN/day & $\begin{array}{c}2.50 \text { PLN/day * single } \\
\text { component of } \\
\text { advertisement }\end{array}$ \\
\hline $\begin{array}{l}\text { Yearly total costs of } \\
462 \text { bank branches }\end{array}$ & 421,000 PLN & $\sim$ 1,222,000 PLN & no data \\
\hline
\end{tabular}

Source: own elaboration.

For interpretation of Variant 1 and establishing the maximum rate of the constant fee component, the costs of the bank brand could increase by more than 421 thousand PLN per year. Basing off of the other two variants of interpretation, the annual costs might be several times higher.

The variable component of the advertising fee, calculated based on the surface area of billboards and advertising devices, might lead to the bank brand enduring additional costs of up to 500,000 PLN per year.

\subsection{Rules and conditions for locating signboards and advertising devices}

An advertising fee can be established only for an area with binding rules and conditions of locating street furniture, signboards and advertising devices and fences. 
The establishment of such rules and conditions is one of the tasks of a municipally pursuant to the Act on Spatial Planning and Development. The local law should be prepared for the entire territory of the municipality. The resolution includes information about the size, standard of quality and type of materials which can used to make signboards and advertising devices. The resolution can also ban the placement of billboards and advertising devices, excluding signs. With regard to signs (billboard or advertising device which informs users about the office or agency found inside a building), the terms and conditions of its location, such as the size and number of signs placed on the façade, can be specified in the resolution.

It is important to note that the process of passing, such a resolution is rather long and complicated. Before the rules and conditions of locating street furniture, signboards and advertising devices and fences become effective, the mayor or president of the city must publish another resolution (information about the commencement of work on a resolution regarding the rules and conditions of locating street furniture, signboards and advertising devices and fences). Next, the project for the resolution is given to public consultation and approval. Only after these steps are taken can the resolution become effective.

Due to the time-consuming process required for the successful enactment of legislation, the Act on landscape protection should not be considered as an immediate correction of the problem of excessive quantities of signboards and banners in the public space. However, for owners of advertisements, that time give the possibility to prepare for the upcoming changes.

When rules and conditions of locating street furniture, signboards and advertising devices and fences become effective, owners of advertisements will have to adapt to restrictions, terms and conditions specified in the resolution. The rules and dates of such adaptation will be determined in the resolution, but the time allotted will not be less than 12 months.

The new law regarding the rules and conditions of locating signboards and advertising devices could result in a number of changes in advertisements placed on all branches of a bank throughout the entire country. Customizing outdoor advertisements to meet the new requirements will be a timeconsuming process (e.g. legal agreements with the Conservator-Restorer, City Department of Architecture, Administration of Roads) and incur additional costs (legal agreements, new schemes, fabrication and installation of the new signboards and banners).

Locating advertisements in public space without proper authorization results a fine $\left(F_{A F}\right)$ in the amount of 40 times the advertising fee established by the administrative decision. The fine is charged from the date authority proceedings are taken, to the date that the advertisement is adapted to the rules and conditions, or removed $(t)$. In the event of the rate of the advertising fee not having been determined by the municipal council, the fine is calculated based on the maximum rates of the advertising fee specified in the Act on Local Taxes and Fees. The collected fine is the income of the municipality.

$$
F_{A F}=\left(40 * A F_{C}+40 * A F_{V}^{*} S\right) * t
$$

\subsection{Fee for occupying the area of a right-of-way}

Advertising fees, as additional payments to the right-of-way occupation fee, can be the starting point for a discussion regarding the properness of determining advertising surface.

The Law on Public Roads defines the fee of right-of-way occupation as a payment for placing a signboard in the right-of-way (land set aside alongside roads, set out by border lines of the space above and below the ground surface. The fee is calculated as the sum of the amount of square meters of advertising surface multiplied by the number of days of occupying the right-of-way, and by the fee for occupying $1 \mathrm{~m}^{2}$ of roadway. Similarly to the advertising fee, the maximum fee for right-of-way occupation is defined; in the case of fees for placing advertisements in the right-of-ways of public roads, such a fee is 10 PLN per day of occupying the right-of-way, for $1 \mathrm{~m}^{2}$ of advertising surface. The rate of the fee for roads managed by the General Directorate for National Roads and Motorways is established by the Decree of the Minister of Infrastructure of 18 July 2011 on the rates of fees for occupying the right-of-way of roads administered by the General Director for National Roads and Motorways (Journal of Laws of 2014. pos. 1608). In the case of roads managed by local governments, their constitutive organs decide on the amount of fees for occupying $1 \mathrm{~m}^{2}$ of right-of-way by means of resolutions. When setting the rates, competent authorities account for the category of the road whose right-of-way is occupied and the type of element in the occupied right-of-way. Important factors in 
determining the rates are also the type of device or building structure, form of occupying the right-ofway, and width of the occupied right-of-way.

Right-of-way occupation without proper authorization, exceeding the deadline specified in the permit or in the event of the area being larger than agreed on in the permit, results in the road manager issuing a fine in the amount of 10 times the fee for road area occupation established by the administrative decision.

The interpretation of the above regulations differs depending on the given road administrator (for more see: PŁUCIENNIK, HEŁDAK, WERNER 2015). The elements that make up the external markings of bank outlets are also treated selectively by road managers. For the majority of them, only signboards are considered to be objects in the right-of-way. Banners mounted on the facades of buildings are regarded as equipment included in the right-of-way in the case of 19 bank locations in 10 cities in Poland.

Amendments to the law, particularly the establishment of an advertising fee, could lead to an increase in the surface area of bank advertisements from $120 \mathrm{~m}^{2}$ to $2,500 \mathrm{~m}^{2}$ if banners are to be treated as objects in the right-of-way. Subsequently, the occupation of the right-of-way will cover 329 bank branches, and the costs will increase more than sevenfold as compared to the current rates of the fee (Table 2).

Table 2

Changes in right-of-way occupation fees

\begin{tabular}{lcc}
\hline & Now (2015) & $\begin{array}{c}\text { Act on Landscape } \\
\text { Protection }\end{array}$ \\
\hline $\begin{array}{l}\text { Number of bank branches } \\
\text { with right-of-way occupation }\end{array}$ & 217 & 329 \\
\hline $\begin{array}{l}\text { Number of bank branches with } \\
\text { banners in right-of-way }\end{array}$ & 19 & 329 \\
\hline Surface area of banners & $\sim 120 \mathrm{~m}^{2}$ & $\sim 2500 \mathrm{~m}^{2}$ \\
\hline Yearly costs of banners & $\sim 83,000$ PLN & $\sim 1,729,000$ PLN \\
\hline Yearly costs of signboards & $\sim 200,000$ PLN & $\sim 200,000$ PLN \\
\hline Yearly total costs & $\sim 283,000$ PLN & $\sim 2,000,000$ PLN \\
\hline
\end{tabular}

Source: own elaboration.

\subsection{Estimating Bank Expenses}

Because of the modifications in the definition of an advertisement and establishment of an advertising fee, the selected bank brand will have to allocate additional funds to advertising in its budget. Precise determination of future expenses is an intricate problem, due to the complexity of the issue and various possibilities of interpreting the Act on landscape protection. The estimation of expenses incurred by banks is calculated assuming the proportionality of current binding rates to statutorily defined maximum rates.

Table 3 presents current and estimated costs of advertisements located in public space. The amounts of fees clearly demonstrate the significance of the problem. As a result, the Act on landscape protection poses a risk of a several-fold increase in annual bank expenses for advertisements placed on all branches of the bank throughout the country.

Current fees of right-of-way occupation by advertisements (283,000 PLN) will unquestionably increase in the following year. Depending on the interpretation variant of the Act on landscape protection and rates of fees, advertising fees will generate comparative or even higher costs of rightof-way occupation. In addition, controversies regarding the new type of payments might provoke discussions regarding the previous methods of calculating fees. Changes in how banners are treated 
are especially important to bank brands due to the possibility of fees increasing from 83 thousand PLN to up to 12 million PLN.

Table 3

Current and estimated costs of advertisements located in public space

\begin{tabular}{lccc}
\hline & Currently costs & Estimated costs & Maximum costs \\
\hline $\begin{array}{l}\text { Right-of-way occupation fee - } \\
\text { signboards }\end{array}$ & 200,000 PLN & 200,000 PLN & $1,900,000$ PLN \\
\hline $\begin{array}{l}\text { Right-of-way occupation fee - } \\
\text { banners }\end{array}$ & 83,000 PLN & $1,700,000$ PLN & $12,000,000$ PLN \\
\hline $\begin{array}{l}\text { Constant component of advertising } \\
\text { fee }\end{array}$ & - & 45,000 PLN & $\begin{array}{c}421,000 \text { PLN }^{*} \\
* \text { depends on } \\
\text { interpretation variants }\end{array}$ \\
\hline $\begin{array}{l}\text { Variable component of advertising } \\
\text { fee - signboards }\end{array}$ & - & 5,000 PLN & 38,000 \\
\hline $\begin{array}{l}\text { Variable component of advertising } \\
\text { fee - banners }\end{array}$ & - & 28,000 PLN & 242,000 PLN \\
\hline $\begin{array}{l}\text { Variable component of advertising } \\
\text { fee - sticks on windows }\end{array}$ & - & 24,000 PLN & 225,000 PLN \\
\hline Annual total costs & 283,000 PLN & $2,000,000$ PLN & $14,800,000$ PLN \\
\hline
\end{tabular}

Source: own elaboration.

\section{Conclusions}

The recently introduced Act on landscape protection is a tool dedicated to municipalities, consisting of rules and conditions for regulating sustainable development, spatial order and landscape protection, and also the quantity and quality of advertisements in space. According to the Act, the municipal council acquires the authority (though not an obligation) to establish advertisement locations and fees, all under a single instrument of law for all of their territories.

Advertisement owners, especially corporations possessing a distribution network (e.g. banks, chains of shops) will be subject to a significant increase in the costs of advertisements located in public space. There is also a risk that they will be obligated to remove signboards and banners from public space. If a prohibition of placing advertisements becomes effective, the owners will notice a significant negative effect of their market share. However, the risk of such prohibitions is smaller for marking the outside of a selected bank branches as compared to large-scale outdoor advertising.

Current interpretation describes an advertisement as a flat object of visual information, along with its construction elements and fixings, used for advertising exposure, in particular signboards and banners, advertisements attached to the windows of buildings, and advertisements placed on the scaffolding, fence or equipment of construction sites, with the exception of small, everyday items used for their intended purpose. The research showed that amendments to the definition of an advertisement were the reason behind the increase in the amount of outside markings treated as advertisements located within the right-of-ways of roads. For many companies, advertisements attached to the windows of buildings will be the main reason for the increase in fees.

Outdoor advertising is connected with the right-of-way occupation fee. The Act on landscape protection establishes a new type of fee, i.e. an advertising fee, which is an extra payment on top of the right-of-way occupation fee. For banks, such a charge is an unequivocal indicator of increased expenses.

Big companies are known to place many signboards and banners in the right-of-way of roads, thus fees incurred for such advertisements are estimated in the hundreds of thousands of PLN. For the analyzed bank brand, advertisement fees will cause increased costs, even several times higher than current payments, i.e. 285,000 PLN (yearly). The new regulations might provoke discussions regarding the types of advertisements and how they affect fees. If roads managers change their perception of banners, the given bank will have to spend nearly 2 million PLN per year for its bank 
branch locations. If the rates of fees are changed and set at their maximum levels, the bank will have to spend as much as 15 million PLN per year.

The Act on landscape protection is not always clear and is subject to different interpretations. This statement refers to the constant component of the advertising fee, which can be defined as a payment for one bank branch location or payment for every kind of outdoor advertisement in a given bank branch location, or even as a payment for every unit of outdoor advertising in a given bank branch location.

It should be mentioned that these expenses only relate to administrative fees. Indirect costs should also be taken into consideration when planning the upcoming annual bank budget. Locating advertisements in public space without proper authorization results in a fine in the amount of 40 times the advertising fee established by the administrative decision per day.

The research shows the complexity and importance of the problem of placing advertisements in public space. It is possible that some of the companies exposed to high costs, in particular individual business, will resign from the external marking of their outlets. On the other hand, municipalities will see a significant increase in the income to their budget. Additional funds can be spent on improving the quality of public space, sustainable management, as well as new investments and projects for the local communities.

It should be noted that the process of reaching a final resolution is long and complicated. Before the resolution can be adopted, the municipal council must execute a series of legal steps. The local law regarding the rules and conditions of locating street furniture, signboards and advertising devices and fences, must be preceded by another resolution by the president/mayor. Next, the project for the resolution is subject to public consultation and approval. Only after these steps are taken does the resolution become effective. Therefore, the amendments to the Law are not a quick tool for regaining spatial order in regards to advertisements.

It is predicted that 2016 will be a transition year, in which many uncertainties in the regulations will be explained. It is also predicted that the Act on amending certain acts in connection with the strengthening of landscape protection tools of 24 April 2015 will lead to an increase in municipal incomes.

\section{References}

BENEDIKT A., 2004, Reklama jako proces komunikacji (Advertising as a Communication Process) [in Polish], Wrocław, p. 113.

BerKovitz E. N., Kerin R.A., HARTley S.W., 1994, William ruderlıus, Marketing, 4. Ed. Irwin Inc.

Bhargava, M., Donthu, N., 1999, Sales Response to Outdoor Advertising, Journal of Advertising Research, 39, pp. 7-18.

CZECH M., KROPIEWNICKA, OSTROWIECKI D.,2014, Reklama częścia krajobrazu - nowe regulacje prawne dotyczace reklamy zewnętrznej w świetle prezydenckiego projektu ustawy o zmianie niektórych ustaw w związu ze wzmocnieniem narzędzi ochrony krajobrazu (Advertising as Part of the Landscape - New Regulations on Outdoor Advertising in the Light of the Presidential Draft Bill on the Amendment of Certain Acts in Connection with the Strengthening of Landscape Protection Tools) [in Polish]. Przegląd Prawa Ochrony Środowiska (Environmental Law Review), 2/2014.

GulmeZ M., KARACA S., KITAPCI O., 2010, The Effects of Outdoor Advertisements on Consumers: a Case Study, Studies in Business and Economics, Vol. 5, Issue 2, pp. 70-88.

KAMiCAITYTE-ViRbaSIENE J., SAMUCHOVIENE O., 2013, Free Standing Billboards in a Road Landscape: Their Visual Impact and Its Regulation Possibilities (Lithuanian Case). Environmental Research, Engineering and Management, 2013. No. 4(66), pp. 66-78

KALINOWSKA D., 2007. Czucie i wiara silniej mówiq o mnie (Feeling and Faith Say More about Me) [in Polish], "Press", No. 11.

Lichtenthal, J. D., YADAVA V., DONTHUB N., 2006, Outdoor Advertising for Business Markets, Industrial Marketing Management, 35, (2006), pp. 236-247.

MikolajczaK-Degrauwe K., Brengman M., 2014, The Influence of Advertising on Compulsive Buying The Role of Persuasion Knowledge, Journal of Behavioral Addictions 3(1), pp. 65-73.

Neuner, M., RAAB, G., ReISCH, L. A., 2005, Compulsive Buying in Maturing Consumer Societies: An Empirical Re-inquiry, Journal of Economic Psychology, 26(4), pp. 509-522.

Outdoor Advertising Control Practices in Australia, Europe and Japan, 2011, FHWA International 
Technology Scanning Program, United States.

PeUCIENNIK M., HeEDAK M., WeRnER E., 2015, Fees for Advertisements in the Right-of-Ways of Public Roads Incurred by a Given Bank Brand in Poland, Real Estate Management and Valuation, Vol. 23, No. 4, pp. 52-61.

Rozporządzenie Ministra Infrastruktury z dnia 18 lipca 2011 roku w sprawie wysokości stawek opłat za zajęcie pasa drogowego dróg, których zarzadca jest Generalny Dyrektor Dróg Krajowych i Autostrad (Dz. U. z 2014 r. poz. 1608 ) (Decree of the Minister of Infrastructure of 18 July 2011 on the rates of fees for occupying the right-of-way of roads administered by the General Director for National Roads and Motorways) (Journal of Laws of 2014, Item 1608)).

TAYLOR, C. R., CHANG, W., 1995, The History of Outdoor Advertising Regulation in the United States, Journal of Macromarketing, 15(1), pp. 47-59.

Ustawa z dnia 24 kwietnia 2015 r. o zmianie niektórych ustaw w zwiazku ze wzmocnieniem narzędzi ochrony krajobrazu (Dz. U. 2015, poz. 774) (Act on Amending Certain Acts in Connection with the strengthening of Landscape Protection Tools of April 24, 2015 (2015 Journal of Laws, Item 774)).

Ustawa z dnia 21 marca 1985 r. o drogach publicznych (Dz. U. 2015, poz. 460). (Act on Public Roads of March 21, 1985) (consolidated text, 2015 Journal of Laws, Item 460)).

Ustawa z dnia 27 marca 2003 r. o planowaniu i zagospodarowaniu przestrzennym (Dz. U. 2015 r. poz. 199 z późn. zm.) (Act on Spatial Planning and Development of March 27, 2003 (consolidated text, 2015 Journal Of Laws, Item 199 as amended)).

Ustawa z dnia 12 stycznia 1991 r. o podatkach $i$ opłatach lokalnych (Dz. U. 2014 poz. 849 ze zm.) (Act on local taxes and fees of January 12, 1991 (consolidated text, 2014 Journal of Laws, Item 849 as amended)). 